\title{
The Effect of Students' Experience with the Transition from Primary to Secondary School on Self-Regulated Learning and Motivation
}

\author{
Ana Uka ${ }^{1, *}$ and Arban Uka ${ }^{2}$ \\ 1 Department of Educational Sciences, Beder University College, 1011 Tirana, Albania \\ 2 Department of Computer Engineering, Epoka University, 1032 Tirana, Albania; auka@epoka.edu.al \\ * Correspondence: auka@beder.edu.al
}

Received: 23 August 2020; Accepted: 13 October 2020; Published: 15 October 2020

check for updates

\begin{abstract}
The transition from primary to secondary school is more successful when students' learning is consistent. Students are also more likely to enjoy school, engage with learning, and have a high academic achievement in secondary school when they feel motivated. This is a critical aspect, especially in cases in which global pandemic situations allow only online schooling opportunities. Students that are away from school lack the traditional sources of motivation and self-regulated learning skills; thus, research is needed to identify other important factors that can be developed in remote settings. The aim of this study was to find out how students perceive their experience with the transition from primary to secondary school and how such a transition influences students' self-regulated learning (SRL) and motivation. Self-reported data were collected during the COVID-19 breakout from a total of $n=80$ sixth and seventh grade students aged 12-14 years old. The results showed that students had a successful transition, especially when they were supported by their parents and teachers. Next, bivariate Pearson correlation analysis indicated that students' perceptions about their experience with the transition from primary to secondary school, their self-regulated learning, and their motivation were significantly correlated. No gender differences were found among any of the main study variables. Teachers can foster students' SRL skills by implementing effective teaching methods and by guiding them towards SRL-enhancing techniques.
\end{abstract}

Keywords: motivation; self-regulated learning; transition; secondary school; COVID-19

\section{Introduction}

Albania has a high Net Enrollment Rate of $96 \%$ in primary education. With an education expenditure of $3 \%$ of the GDP, Albania's education system is struggling to accomplish the goal of preparing students with 21st century skills and to meet the Sustainable Development Goals (SDGs; SDG-4) and national education goals [1]. The Albanian pre-tertiary education system includes pre-school education, basic education (comprising primary and lower secondary education), and upper secondary education (often referred to as secondary education). Only basic education is compulsory, and increased from eight to nine years in 2012, a duration similar to the length of compulsory schooling found in member countries of the Organisation for Economic Co-operation and Development (OECD) [1].

In 2016, Albania adopted the national Pre-University Education Development Strategy for 2014-2020, which also set the strategy priorities, such as improving the governance, leadership, and management capacities of pre-university education system resources [2]. However, the Albanian education system still lacks the resources and infrastructure to provide quality education and equal opportunities in traditional settings comparable to the regional and European educational systems for all students. 
The world has recently been fortunate to offer educational opportunities in the traditional settings, and local challenges have rarely been observed because of pandemic breakouts [3]. Unfortunately, the global COVID-19 breakout has forced educators around the world to switch to unplanned remote educational settings $[4,5]$. This is a challenge for the educational institutional leadership, for the teachers, and, of course, for the students as well [6-8]. One critical stage of education that deserves great attention is the transition from primary to secondary school, especially during the schools' lockdown because of the COVID-19 pandemic [9]. It is well established in the literature that the transition from primary to secondary school is an important step in educational life, and is associated with both positive and negative effects with respect to the child's education and socio-emotional development [10]. As students struggle with adjustment, they also experience changes in social competence, learning environment, and learning needs [11]. This transition has been hindered more by the lockdown of the schools due to the COVID-19 pandemic. The difficulties for this group of students may stem both from the lack of technological resources, such as laptops or a cell phones, and from the lack of self-regulated learning (SRL) skills [12]. Non-optimal conditions-distance education is a major one-lead to high dropout rates and low academic performance [3]. At this stage, the identification of factors that can compensate for the inevitably difficult working conditions is essential.

The course pattern of students' SRL and motivation during school years is an area of interest across different contexts, especially as studies show that students' learning and motivation decline as they go through compulsory education $[13,14]$. Studies conducted in the field of educational psychology and, in particular, in school contexts have been mainly focused on how students' SRL process and motivation change during their middle school years [15]. Students' SRL and motivation are two important and strongly correlated constructs, which are highly sensitive to their experiences with transition within an educational setting. These two overlapped components are often characterized by students' motivational beliefs, cognitive schemes, and metacognitive skills [16-18].

Scholars agree that students have the ability to regulate their learning and motivation, which have a direct impact on students' ability to enjoy school, engage with learning, and succeed academically [18]. However, students' experiences with transitions as they pass through compulsory education may interrupt their SRL process and motivation and put the child at risk of developing certain disruptive behaviors during both face-to-face and online learning. Teachers should find effective ways on how to match corresponding online teaching methods with students' learning needs in different subjects to better increase students' learning interest and creativity [19].

In Albania, a large number of students continue to leave school without mastering basic competencies, such as self-regulated learning skills and motivation, which remains an issue, especially among middle school students. Due to the differences among countries in terms of educational infrastructure and learning conditions, it has been very difficult for the Albanian educators to find evidence on how to adapt other models of SRL and motivation to the Albanian students' profile. Different teaching models have been developed to support students' learning, but it is still not clear which self-regulated methods are effective and how they can help students stay motivated during their transition in the face of the pandemic. Studies have been very limited on investigating how students experience the transition to secondary school and how this shift may influence students' learning process during unusual times without face-to-face teacher guidance and institutional guidance and counseling [19]. With the spread of the internet and associated development in technology, e-learning has found common use in education [20-22]. This new trend started in higher education with the contribution of online educational platforms like Coursera, EDX, etc. [23,24]. Since then, researchers have focused on how educational parameters like SRL and motivation [25] are modified in online settings. Barnard-Brak et al. (2010) identified different profiles of self-regulated learners in remote learning [26]. Patterns of SRL and motivation have been investigated, with the former being more easily measurable, as it can be extracted even from timely submission of compliance with students' periodic assignments [27]. This body of research could be complemented with new data 
coming from the lockdown period, as it affects all the students equally. During these unfortunate times, the student population can be used as a testbed to better understand the educational patterns and outcomes. In this study, we aim to investigate the experience with the transition from elementary to secondary school and how it affects SRL and motivation during a national lockdown. We want to add that such studies are hard to design, as no one can predict the next lockdown and its time duration.

The focus of this article is on students' experiences with such a transition and its impact on their SRL and motivation during the pandemic. More specifically, this study aimed at investigating the following research questions: (1) How do students perceive the experience with transition from primary to secondary school during the pandemic? (2) Are there significant gender differences in the way that students experience the transition from primary to secondary school during the pandemic? (3) What is the relationship between students' experience with the transition and their self-regulated learning skills? (4) What is the relationship between students' experience with the transition and their motivation during the pandemic? This study adds value to the current literature at a global scale, considering only the fact that this study was conducted at a later time than the previous studies. The argument is stronger when we want to analyze gender-based differences. The expectations from women in the labor market have changed drastically for good, as women are represented more in legislation, in management, and in other areas. As the expectations for women have changed, this may reflect directly in their choices, persistence, and motivation. So, the data analyzed in this study provide a timely updated picture of the important variables for women. At the same time, this study was conducted during the global pandemic and provides a picture during a globally challenging situation. At a local scale, this study contributes in the understanding of important variables of students in Albania. A follow-up study employing the same research design after the lockdown, when students conduct face-to-face learning, would further contribute to the understanding of educational models. This study comes up with several recommendations for secondary schools on how to help students experience a positive transition to middle school and improve students' SRL skills and motivation, especially during pandemics.

\section{Theoretical Framework}

\subsection{Students' Transition from Primary to Secondary School and SRL}

SRL has received more recognition in the field of educational sciences over the last three decades. Researchers have come to the conclusion that there is no clear and precise definition of self-regulatory capacity. As a construct, it includes different functions related to cognition, decision-making, problem-solving, conceptual change, metacognition, and motivation [28]. SRL is a learning process that is goal oriented, conscious, and individually controlled, which includes skills such as trying to gain familiarity with a complex problem, learning a new language, studying for an exam, or learning how to play guitar [29]. SRL has been considered as a construct functioning as a mediator between individuals' self-regulatory skills and their own cognitive processes within their learning environment [30]. SRL is one aspect of the self-regulation process, which includes skills about planning the learning process and setting their own goals, learning strategies, and self-reinforcement. Current models of SRL explain the way students monitor their behaviors, choose goals, and select learning strategies.

There are different definitions of SRL, but three elements seem to be important for students' academic performance. The first one includes metacognitive approaches used for developing and altering their cognition [31]. The second element consists of management tasks to keep students cognitively focused on the task, leading to a better performance. The third element is related to the cognitive approaches that students use to comprehend the material [31]. A self-regulated learner is effective when the learner is able to manage the strategies to absorb and understand knowledge, analytically evaluate it, and effectively use it to solve problems [32-34]. 
The Social Cognitive Theory developed by Bandura (1986) has been used as a conceptual framework because of the explanatory value for understanding human development and applications in children's learning. Bandura's Social Cognitive Theory focuses on individuals' learning, improvement, attainment of knowledge, and self-regulated skills within a social context, in which parents, peers, and teachers have an important role as social models for children. Bandura (2006) describes his theory as "cognitive", not "behaviorist". He argues that people learn by observing others without being directly reinforced.

Bandura's theory was in itself a complete change from the behavioral perspective to a social-cognitive approach. Therefore, he developed a conceptual and analytical model called Triadic Reciprocal Determinism (TRD), as shown in Figure 1. This model represents bidirectional relationships among an individual's behavior, personal factors, and the environment. In other words, it means that these three components are continually interacting with one another. Reciprocal determinism suggests that children play an active role within a learning environment. Their learning is not simply a process developed through learned associations or reinforcements, but their own personal characteristics influence the way they interact with the world as well.

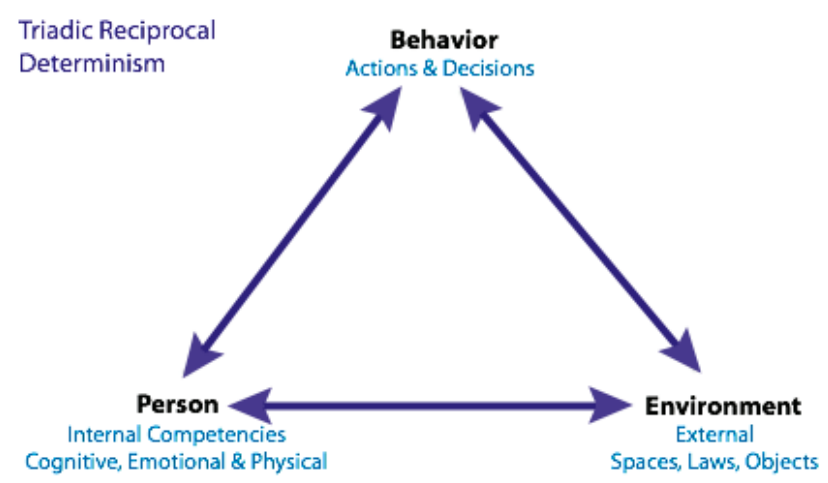

Figure 1. Triadic Reciprocal Determinism model.

Among many scholars, such as Boekaerts (1995, 1996a, 1996b) [35-37], Borkowski and colleagues (2000) [38], Winne and Hadwin (1998), and Zimmerman (1990a,b, 1998, 2000a), who have developed different SRL models of high quality supported by several empirical studies, Pintrich's model seems to be most influenced by the Social Cognitive Theory of Bandura (2000) [39-42]. Pintrich defined SRL as a goal-oriented process. He focused more on the constructive nature of SRL, which includes a range of factors consisting of cognitive, motivational, psychological, and social factors. Both Bokaerts and Pintrich focused their work mainly on motivation, indicating that there exist significant relationships between motivational factors, SRL, and academic performance [30].

From the social cognitive perspective, Zimmerman and colleagues (1989) identified three important components of SRL [43]: (1) self-observation [44]; (2) self-judgment, and (3) self-reactions. As the individual tries to reflect about the achievements and goals and makes all of the efforts to accomplish those, at this point, the individual has effectively become self-regulated. During the school years, teachers usually aim at developing and producing self-regulated learners by using different strategies and approaches, such as the Information Processing Model. As students store the information into long-term memory, they can retrieve it upon demand and apply it to tasks, making them self-regulated learners.

As shown in Figure 2, Zimmerman and colleagues (1996) identified a self-regulatory learning cycle followed by four steps that can be implemented to enable students to develop five crucial academic skills: (a) planning and studying effectively, (b) comprehending and rolling up a text material, (c) developing note-taking skills, (d) studying and preparing for exams, and (e) writing more effectively. This model explains the strategies that should be followed to enable students to self-observe their current study practices more precisely, to identify which study methods are unproductive, and, instead, to develop and implement other effective study strategies. In this respect, students need social support, 
and especially teachers' support by providing opportunities to become more self-regulated and by monitoring students' learning to facilitate the students' experience with the transition and to help the children sustain the self-regulated learning process.

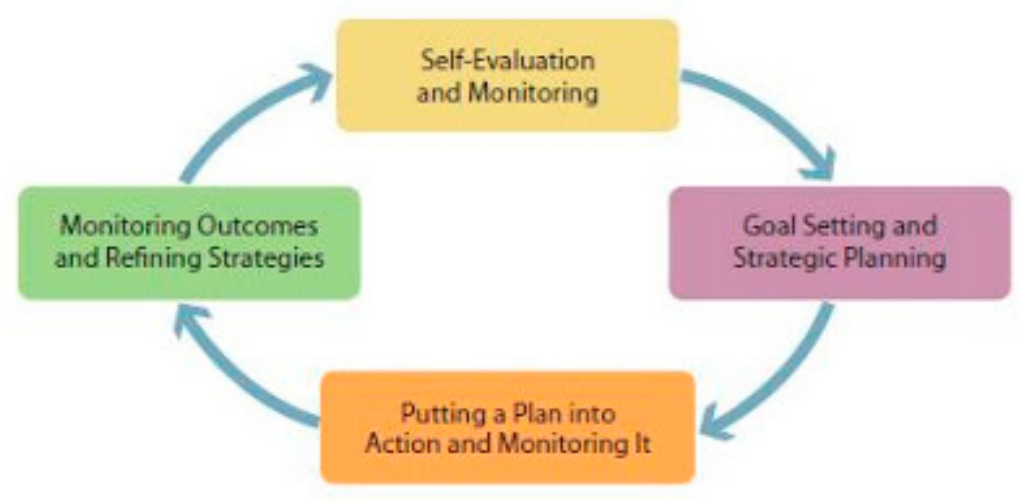

Figure 2. A model of self-regulated learning.

Scholars claim that students who self-regulate their learning actively adjust their thoughts, feelings, and behaviors as required to influence their learning practices and motivation [28]. According to the literature, SRL during the transition from primary to secondary school is influenced by a range of factors. Students' experience in secondary school may be a result of a combination of these factors from previous experiences [45]. Children's actions are guided by adults. Through interactions with adults, children experience the transition of behaviors regulated by others toward self-regulated ones. This transformation of behaviors occurs when children start developing the capability to use their speech. Researchers have identified that other developmental changes that occur during the transition from primary to secondary school are characterized by an increase in the use of setting goals, planning, and study habits. Meece (2008) reported that children of younger age conceptualize studying as the act of going through the materials, whereas older students engage in note-taking and underlining [46]. In addition, younger children are not capable of following their comprehension [47]. Older children are able to define instabilities in the material, and once they find them, they act by rereading to ensure that they read accurately [48]. As children grow older, they improve their regulatory activities, including planning, goal setting, ensuring comprehension, analyzing progress, and modifying strategies as necessary.

From the teachers' perspective, being organized is the most challenging skill for students transitioning to middle school [49], especially during extraordinary times. Students can successfully move to the secondary school as they become independent, develop organizational skills, and are able to self-regulate learning and to be motivated to learn as they are supported by their teachers and parents. Coffey et al. (2013) report a completely unique case because they analyzed the immediate transition from elementary to secondary education of more than 100 schools in a move to unify the educational system across all of Australia [49]. Similar experiences in Australia have led researchers to develop a pedagogical transition framework contributing to SRL by adapting several interrelated principles into the curriculum under normal educational conditions [50]. First, regarding transition, they propose that the curriculum should be developed to be stable and to support students' transition from their previous learning experience to the kind of learning in secondary education. Second, the first-year educational program should be: (i) student-centered, explicit, and aiming at providing the foundation and framework necessary for first-year learning achievement, (ii) evidence-based and improved by continuous evaluation that results in curriculum development, (iii) accessible to students of all diversities and inclusive, (iv) inclusive and enabling for active and collaborative learning, including peer-to-peer collaboration and teacher-student interaction, and (v) facilitating towards students' transition. They provide several suggestions on how to implement the above aspects, such as by providing grace periods to help student develop confidence, placing students with children 
they already know, etc. Especially in online teaching activities, teachers should comprehend more deeply the discipline they cover, and should adopt a variety of teaching methods to train students' thinking in subject learning so that students' academic performance can be improved [19]. In the case of online learning environments, contributing to stronger students' SRL is essential, and for this reason its assessment helps in the construction of supportive models. At the same time, it is reported that online learning directly supports SRL, and a careful analysis of the sample analyzed here may shed more light on the model [51].

\subsection{Students' Transition from Primary to Secondary School and Motivation}

Students' motivation is considered as one of the most significant determinants of the learning experience at school [52]. Many studies explored the reasons why students make an effort and engage in learning [15]. The links between students' experiences with the middle school transition and academic motivation and achievement during secondary school years are not well understood in the literature [53]. As students at this age become more self-conscious and involved with peers, their need for autonomy increases as well, and teachers find it more difficult to implement democratic and autonomy-related classroom strategies that may influence students' learning practices. This gap created between students' needs and environmental factors negatively influences academic motivation and achievement $[54,55]$. These widely reported challenges can be overcome by the transition framework, as it offers several suggestions that lead to a more familiar environment by associating students in the education stage with their friends that they had in the past, by creating a student-centered system, and by training teachers on how to pass the transition stage.

This field of research has been mainly dominated by the self-determination theory (STD) over the last four decades $[56,57]$, which has been used as a conceptual framework to understand the role of motivation in students' learning. This is a macro-theory of human motivation, which has been in the focus of various contexts. STD argues that the type of motivation driving a certain behavior can have a high impact on physiological and psychological functioning. Deci and Ryan $(1991,1995)$ have identified three general types of motivation: intrinsic motivation, extrinsic motivation, and amotivation [56,57]. Intrinsic motivation, which is also considered as a self-determined type of motivation, includes participation in activities for different reasons, such as for pleasure, learning, or task completion. Extrinsic motivation drives behaviors, which are displayed mainly because they lead to positive outcomes. Lastly, amotivation is the absence of motivation defined as the lack of desire, intention, or ability [58].

Other scholars such as Pintrich and De Groot (1990) tried to conceptualize student motivation by adopting an expectancy value model of motivation categorized into three motivational components: (i) an "expectancy" component that consists of students' beliefs about completing a task; (ii) a "value" component that includes students' goals and beliefs related to the importance and interest of the task; and (iii) an "affective" component, which is about students' emotional responses to the task [59]. There exist various goals that motivate students during their years of schooling [60]. The trichotomous model conceptualized by Elliot and Harackiewicz (1996) differentiated between three kinds of goals: mastery, performance-approach, and performance-avoidance goals. Students oriented towards mastery-approach goals aim at developing different skills and mastery, and are confident about being able to do so [61]. Students with a performance goal orientation strive at demonstrating competence by achieving high grades and superiority over peers. The aim is to demonstrate their ability in comparison to the others to show them what they have achieved. Lastly, students with a performance-avoidance orientation try to positively influence the others: They do not want to perform worse than others [62]. Studies show that students oriented mostly towards mastery goals are more motivated and self-regulated than those with performance goals [63-66].

A review of the literature indicates that moving to a new and larger learning environment greatly influences students' learning practices and motivation [53]. This shift of the students to an upper level of education is associated with a number of social, educational, and developmental 
issues, such as disruptions of social networks, less individual attention from teachers, 'forcing the limits' as an attempt to adjust to a new learning environment, weakening the student's self-concept and capability to cope well, less motivating teacher methodology, leading to students' diminished interest and engagement, and peer pressure, resulting in running away from classes, low academic performance, and engaging in risk behaviors $[67,68]$. As such, students have to reconstruct their identities, including their self-efficacy, self-esteem, social competence, and academic standing within a mixed network of new peers and multiple teachers in circling class sessions [69-71].

Different studies point out at a range of factors that may influence students' motivation during the transition to secondary school [72-76]. The social-environmental factors seem to have an impact especially on students' intrinsic motivation, including the motivational climate, classmates, teaching practices, learning materials, and adult support [75]. Classroom experiences may have an effect on motivation because, when students view the classroom environment positively and they have positive perceptions of progress and competence [77], they are more likely to feel both intrinsically and extrinsically motivated and have a sense of belonging [74]. As children grow older, their intrinsic motivation plays an especially important role in shaping their perceptions about learning development and beliefs about their capabilities [78]. Harter, Whitesell, and Kowalski (1992) suggested that changes in structures and sizes of school may contribute to motivation and academic performance [79]. Particularly, they proposed that environmental changes force students to embrace a more extrinsic orientation towards schoolwork, linking to more objective self-evaluations. An influential factor that may facilitate students' transition are the teachers, who are considered as the driving force that helps students stay motivated at school [80,81]. Influential teachers plan a goal-oriented class session, create an attractive and encouraging learning environment, provide clear and consistent tutoring, and support students with learning cues [60].

\subsection{Effect of Gender on Students' Transition from Primary to Secondary School, SRL, and Motivation}

Researchers have always focused on the gender effect on several variables related to the educational domain. Even though the common perceptions propose a gender difference, results obtained from studies carried out over at least five decades provide mixed conclusions. One should compare the results of similar studies conducted at different timeframes, as the world has been changing drastically. The demographic changes and the decrease of fertility have led developed countries to take several measures to facilitate a better balance between work and family [82]. As a result of the measures taken, an increase of participation of women in legislation [83], in management [84], in the IT workforce [85], and in other areas [86] is observed. This change of expectations from women should also reflect on the factors that are related to education during all stages. In a recent study involving nursing students in Turkey, women were found to score significantly higher than men in terms of self-directed learning readiness (SDL) [87]. Contrary to this result, no gender difference was observed in SDL for nursing students in Australia [88]. In a detailed meta-analysis, it was reported that even if gender-based differences in some educational domains ever existed, they are not present any more [89]. For a more comprehensive review on the effect of gender, we refer to References [90-92]. There is a difference between achievement and gender-based choices and effort. The underrepresentation of women in certain areas indicates a difference in choice. Pintrich and Zusho (2002) report that there is a difference between genders in effort, choice, and persistence [90]. In line with this result, one could expect a difference in SRL and motivation. We compare the scores between the genders for the three variables that we have analyzed and report the results in Section 4.

\section{Method}

\subsection{Participants, Sampling, and Procedure}

A convenience sample of $n=80$ students (47 females, 58.8\%, and 33 males, $41.2 \%$ ) aged $12-14$ years $($ Mean $=12.23, \mathrm{SD}=0.86)$ old who attended the sixth and seventh grades in different 
schools of Tirana city and who reported about their experience with the transition from primary to secondary school during the pandemic was included in this study. The participants were recruited by using convenience sampling, which is a type of non-probability sampling technique. A total of 120 questionnaires were distributed to middle school students via Google Forms to obtain information about their self-regulated learning, motivation, and experience with the transition from primary to secondary school. The return rate was $67 \%$. Participants were informed about the aim of the study and where these data were to be used. They were assured about the anonymity and confidentiality of the data.

\subsection{Measurement Tool}

This study used a quantitative research design via survey methodology. The questionnaire used for the purpose of this study consisted of two parts. The first part consisted of questions about demographic information. The second part included a set of questions used to measure students' experience with the transition from primary to secondary school, their motivation, and their self-regulated learning skills. The items of the exploratory survey were on a Likert-type scale (from $1=$ "Strongly Disagree" to $5=$ "Strongly Agree"), which was used to measure the main variables of this study [17].

\subsection{Measures}

Experience with transition: This scale included six items measured by using questions like 'I feel capable of handling my transition to school successfully', or 'There are aspects of my new situation that I can control' [93]. The items measuring this variable were on a Likert-type scale (from $1=$ "Strongly Disagree" to $5=$ "Strongly Agree"). Reliability analysis provided a Cronbach's alpha equal to 0.78 . The normality of the experience with transition variable was tested using the Kolmogorov-Smirnov test, which revealed no significant deviation from the normal distribution for both males $(p=0.1)$ and females $(p=0.06)$.

Self-regulated learning: To measure this study variable, 25 items were used, including questions like 'When I study for a test, I try to put together the information from class and from the book' or 'When I do homework, I try to remember what the teacher said in class so I can answer the questions correctly' [59]. A Likert-type scale was used for the items of this scale (from $1=$ "Strongly Disagree" to 5 = "Strongly Agree"). Reliability analysis provided a Cronbach's alpha equal to 0.93. The Kolmogorov-Smirnov test confirmed a normal distribution of the self-regulated learning variable for both males $(p=0.1)$ and females $(p=0.20)$.

Motivation: The motivation scale consisted of 18 items, where students reported about their motivation by answering questions like 'I am sure I can do an excellent job on the problems and tasks assigned for this class' or 'I prefer class work that is challenging so I can learn new things' [94]. The items measuring motivation were on a Likert-type scale (from 1 = "Strongly Disagree" to $5=$ "Strongly Agree"). Reliability analysis indicated a Cronbach's alpha equal to 0.93 . The Kolmogorov-Smirnov test reported no significant deviation from the normal distribution for motivation measured for both males $(p=0.20)$ and females $(p=0.20)$.

Factor analysis was run to validate the data. To find support for the construct validity of the three measures, an exploratory factor analysis with varimax rotation was conducted to assess the underlying structure for the 49 items of the Self-Regulated Learning and Motivation Questionnaire. Three factors were requested, referring to the fact that the items were designed to index three constructs: experience with transition, self-regulated learning, and motivation. After rotation, the first factor accounted for $18.66 \%$ of the variance, the second factor accounted for $17.4 \%$ of the variance, and the third factor accounted for $8.9 \%$. The first factor, which seems to index self-regulated learning, had strong loadings $(0.40-0.76)$ on the first 25 items. The second factor, which seemed to index motivation, had high loadings $(0.43-0.78)$ on the next 18 items. The third factor, which seemed to index experience with transition, loaded highly $(0.39-0.64)$ on the last six items. Finally, the analysis showed that the 
data do fit into the three constructs, giving us support for the construct validity of the three measures in this sample.

\subsection{Data Analysis}

The data were analyzed by using the Statistical Program for Social Sciences (SPSS) version 20.0. The reliability statistics were used to assess the internal consistency reliability of all the items of each scale of the study variables by providing Cronbach's alpha as a measure of reliability. Then, exploratory factor analysis was conducted to indicate construct validity of the questionnaire used for the aim of this study. Next, frequency distributions and descriptive analysis were used to analyze students' self-regulated learning, motivation, and perceived experience with the transition from primary to secondary school. Then, an independent samples $t$-test analysis was conducted to investigate whether there are gender differences in students' experiences with the transition to secondary school, self-regulated learning skills, and motivation. Finally, bivariate Pearson correlation analysis was used to investigate the relationships between self-regulated learning, motivation, and the experience with the transition to secondary school.

\section{Results}

As shown in Table 1, descriptive analysis revealed the means, standard deviations, range, skewness, and kurtosis for all variables of interest in this study. The frequency distribution analysis shows that the main variables are normally distributed, as indicated by the values of skewness and kurtosis. To investigate how students perceive the experience with the transition, self-regulated learning, and motivation, a descriptive analysis was conducted, which showed that the experience with transition scale has a mean of 3.61 with a standard deviation of 0.71 , the self-regulated learning scale has a mean of 3.67 with a standard deviation of 0.59 , and the motivation scale has a mean of 3.70 with a standard deviation of 0.64 . The results showed that the students reported an above-average experience with the three scales.

Table 1. Students' perceived experience with the transition from primary to secondary school, $n=80$.

\begin{tabular}{|c|c|c|c|c|c|c|}
\hline Variable & M (sd) & Range & Skewness & Kurtosis & Frequency & Percentage \\
\hline $\begin{array}{l}\text { 1. Students' experience with } \\
\text { transition }\end{array}$ & $3.61(0.71)$ & $1-5$ & -0.24 & 0.25 & & \\
\hline $\begin{array}{l}\text { 2. Students' self-regulated } \\
\text { learning }\end{array}$ & $3.67(0.59)$ & $1-5$ & -0.44 & 0.59 & & \\
\hline $\begin{array}{l}\text { 3. Students' motivation } \\
\text { 4. Gender }\end{array}$ & $3.70(0.64)$ & $1-5$ & -0.65 & 0.12 & & \\
\hline Male & & & & & 33 & 41.2 \\
\hline Female & & & & & 47 & 58.8 \\
\hline
\end{tabular}

Note: $\mathrm{M}=$ mean; $\mathrm{sd}=$ standard deviation.

Next, as indicated in Table 2, the independent samples $t$-test analysis showed that males did not significantly differ from females in their experience with the transition from primary to secondary school $(p=0.78)$, self-regulated learning skills $(p=0.46)$, and motivation $(p=0.81)$. Thus, there are no significant gender differences in students' experience with the transition, self-regulated learning, and motivation.

Then, as indicated in Table 3, bivariate Pearson correlation analysis showed that there is a significant positive correlation between students' experience with the transition and their self-regulated learning skills, $r(80)=0.45, p<0.001$, which is considered a large effect size according to Cohen (1988).

Next, as reported in Table 4, the bivariate Pearson correlation analysis revealed that there is a significant positive correlation between students' experience with the transition and their motivation, $r(80)=0.45, p<0.001$, which is considered a large effect size. 
Table 2. Comparison of male and female middle school students on experience with the transition from primary to secondary school, self-regulated learning skills, and motivation $(n=33$ males and 47 females).

\begin{tabular}{|c|c|c|c|}
\hline Variable & M (sd) & $t$ & $p$ \\
\hline Experience with transition & & 0.29 & 0.78 \\
\hline Males & $3.64(0.79)$ & & \\
\hline Females & $3.59(0.65)$ & & \\
\hline Self-regulated learning & & -0.75 & 0.46 \\
\hline Males & $3.61(0.65)$ & & \\
\hline Females & $3.71(0.54)$ & & \\
\hline \multirow{3}{*}{$\begin{array}{c}\text { Males } \\
\text { Females }\end{array}$} & & -0.24 & 0.81 \\
\hline & $3.68(0.66)$ & & \\
\hline & $3.72(0.64)$ & & \\
\hline
\end{tabular}

Table 3. Intercorrelations for the main variables of the study $(n=80)$.

\begin{tabular}{ccc}
\hline Variable & $\mathbf{1}$ & $\mathbf{2}$ \\
\hline 1. Experience with transition &.. & $0.45^{*}$ \\
2. Self-regulated learning &.. &.. \\
\hline \multicolumn{2}{c}{$* 0.001}$. &
\end{tabular}

Table 4. Intercorrelations for the main variables of the study $(n=80)$.

\begin{tabular}{llc}
\hline Variable & $\mathbf{1}$ & $\mathbf{2}$ \\
\hline 1. Experience with transition &.. & $0.45^{*}$ \\
2. Students' motivation &.. &.. \\
\hline & $* p<0.001$. &
\end{tabular}

Finally, as reported in Table 5, the bivariate Pearson correlation analysis showed that there is a significant positive correlation between students' self-regulated learning and their motivation, $r(80)=0.59, p<0.001$, which is considered a large effect size.

Table 5. Intercorrelations for the main variables of the study $(n=80)$.

\begin{tabular}{ccc}
\hline Variable & $\mathbf{1}$ & $\mathbf{2}$ \\
\hline 1. Self-regulated learning &.. & $0.59^{*}$ \\
2. Students' motivation &.. &.. \\
\hline & ${ }^{*} p<0.001$. &
\end{tabular}

\section{Discussion and Conclusions}

This work explored the recent literature regarding students' experience with the transition from primary to secondary school and how this has influenced their self-regulated learning skills and motivation. The analysis of these two factors in different countries with unique educational models is important for online schooling in general, as it facilitates comparisons among various samples and is inevitable in the unfortunate global pandemic situations, like that of COVID-19. The success rate of the transition to the secondary school may be resultantly lower in the new normal conditions as a result of lower levels of self-management and motivation [94]. Although children have a low risk of COVID-19, their personal characteristics are directly and indirectly harmed by the extensive precautions [95]. Moreover, there was evidence that during the transition, rates of students' motivation, school engagement, and attitudes were more likely to decline, while the rates of absence and dropping out were more likely to increase. 
The findings of this study showed that students could handle the transition from primary to secondary school at a moderate level. Transition experiences shape students' emotional reactions to stressful situations, and such processes prepare the motivational grounds for their involvement, burnout, and accomplishments at school [96]. Transition to educational settings characterized by greater discipline and control and reduced quality of teacher-student relationships can hinder students' academic engagement and evoke behavioral problems and school-related fears. Positive experiences with the transition were found to have no gender effect. Other studies similarly reported no gender differences among students' experiences with the transition to secondary school [68]. Next, students believed that teachers, parents, older brothers, sisters, or friends are important sources of information who may facilitate students' transition process. This finding is supported by previous studies, which show that students' perceptions of social support provided especially by older siblings [49], parents, and teachers positively influence students' transition to secondary school $[80,81,97,98]$.

The results also showed a significant positive relationship between students' experience with the transition and their motivation as well as SRL. These findings are supported by the literature, which indicates that these variables are positively correlated, and the way students experience a certain transition affects their cognitive engagement and academic motivation and performance $[59,94,99]$. Similarly to the experience with the transition, no gender difference was observed for SRL and motivation in this study. This result is in line with most of the research in the literature. Pintrich and de Groot (1990) found no gender difference in motivational and SRL components of classroom academic performance for seventh graders [59]. There are studies that have reported a gender difference, with women reporting higher levels of effort and persistence [90], and this could lead to a hypothesis that women have higher motivation, but this was not confirmed.

Teachers can foster students' SRL skills by implementing effective teaching methods and by following the proposed pedagogical transition framework. This framework aims to create a familiar and student-friendly environment, and, as a result, it would strengthen the students' cognitive skills. SRL and motivation are directly related with both managing the capacity for the transition from one educational stage to another in general and managing the capacity for online learning. Considering that SRL is a more obvious variable and is more easily quantifiable by the parents and teachers, the latter should receive proper training on how: (i) to guide students to carry out self-regulated learning and (ii) to choose self-regulated learning materials and methods for students [19]. Huon et al. (2007) reported that student-controlled SRL methods often result in shallow information processing strategies [100]. School leadership should organize periodic training sessions for the teachers so that they can lead their students to better self-management skills and can ensure that the students acquire both the breadth and depth of the material offered in school.

\section{Limitations and Implications for Future Research}

A few limitations and some implications for future research should be noted. This study is focused on two important constructs, which are greatly influenced by students' experiences with the transition. It should be noted that other measures, such as self-efficacy beliefs, social relatedness, or self-esteem, can be included in order to determine the broader range of factors that influence motivational beliefs, students' regulatory skills, and achievement.

Due to the intensive period of the COVID-19 pandemic and the lockdown of the schools, we were limited to collecting the data online and reaching a limited number of respondents through a random sampling procedure. Future studies may consider a more diverse sample in terms of school reputation, student quality, and school location (e.g., urban vs. rural).

A final limitation of this study is the reliance only on student self-reported information about their experiences with the transition and other variables of interest. This way of assessment may lead to inconsistent or inaccurate information due to the inability to remember experiences that happened earlier in time, or it is possible that successful students are more willing to provide a positive profile of experiences, beliefs, and behaviors. Future research can further examine these 
processes by considering data collection from other sources (e.g., teachers and parents) and other forms of assessment, including observations and structured interviews with focus groups.

Author Contributions: A.U. (Ana Uka) designed the study, analyzed the data, wrote the paper; A.U. (Arban Uka) analyzed the data, wrote the paper. All authors have read and agreed to the published version of the manuscript.

Funding: This research received no external funding.

Acknowledgments: We thank Ditmira Abazi for helping with data collection and data entry.

Conflicts of Interest: The authors declare no conflict of interest.

\section{References}

1. Maghnouj, S.; Fordham, E.; Guthrie, C.; Henderson, K.; Trujillo, D. OECD Reviews of Evaluation and Assessment in Education: Albania; OECD Reviews of Evaluation and Assessment in Education; OECD: Paris, France, 2020; ISBN 9789264764804.

2. Wort, M.; Pupovci, D.; Ikonomi, E. Appraisal of the Pre-University Education Strategy 2014-2020; UNICEF Albania: Tirana, Albania, 2019.

3. Achoka, J. In search of remedy to secondary school dropout pandemic in Kenya: Role of the principal. Educ. Res. Rev. 2007, 2, 236-244.

4. Basilaia, G.; Kvavadze, D. Transition to Online Education in Schools during a SARS-CoV-2 Coronavirus (COVID-19) Pandemic in Georgia. Pedagog. Res. 2020, 5. [CrossRef]

5. Daniel, S.J. Education and the COVID-19 pandemic. Prospects 2020. [CrossRef] [PubMed]

6. Brammer, S.; Clark, T. COVID-19 and Management Education: Reflections on Challenges, Opportunities, and Potential Futures. Br. J. Manag. 2020, 31, 453-456. [CrossRef]

7. Huang, R.; Tlili, A.; Chang, T.-W.; Zhang, X.; Nascimbeni, F.; Burgos, D. Disrupted classes, undisrupted learning during COVID-19 outbreak in China: Application of open educational practices and resources. Smart Learn. Environ. 2020, 7, 1-15. [CrossRef]

8. Ferdig, R.E.; Baumgartner, E.; Hartshorne, R.; Kaplan-Rakowski, R.; Mouza, C. Teaching, Technology, and Teacher Education during the Covid-19 Pandemic: Stories from the Field; Association for the Advancement of Computing in Education (AACE): Waynesville, NC, USA, 2020.

9. Galton, M.; Gray, J.; Ruddock, J. The Impact of School Transitions and Transfers on Pupil Progress and Attainment. In Transitions and Transfers: A Review; DfEE Research Report No. 131; HMSO: Norwich, UK, 1999; ISBN 1841850500.

10. Griebel, W.; Berwanger, D. Transition from primary school to secondary school in Germany. Int. J. Transit. Child. 2006, 2, 32-39.

11. Zanobini, M.; Usai, M.C. Domain-specific Self-concept and Achievement Motivation in the Transition from Primary to Low Middle School. Educ. Psychol. 2002, 22, 203-217. [CrossRef]

12. Masonbrink, A.R.; Hurley, E. Advocating for Children during the COVID-19 School Closures. Pediatrics 2020, 146. [CrossRef]

13. Copland, F.; Garton, S.; Burns, A. Challenges in Teaching English to Young Learners: Global Perspectives and Local Realities. TESOL Q. 2014, 48, 738-762. [CrossRef]

14. Pufahl, I.; Rhodes, N.C. Foreign Language Instruction in U.S. Schools: Results of a National Survey of Elementary and Secondary Schools. Foreign Lang. Ann. 2011, 44, 258-288. [CrossRef]

15. Alivernini, F.; Lucidi, F.; Manganelli, S. Assessment of academic motivation: A mixed methods study. Int. J. Mult. Res. Approaches 2008, 2, 71-82. [CrossRef]

16. Garcia, T.; Pintrich, P.R. Regulating motivation and cognition in the classroom: The role of self-schemas and self-regulatory strategies. Self Regul. Learn. Perform. Issues Educ. Appl. 1994, 127-153. [CrossRef]

17. Garcia, T.; Pintrich, P.R. Student Motivation and Self-Regulated Learning: A LISREL Model. Available online: https://eric.ed.gov/?id=ED333006 (accessed on 15 October 2020).

18. Wolters, C.A. Regulation of Motivation: Evaluating an Underemphasized Aspect of Self-Regulated Learning. Educ. Psychol. 2003, 38, 189-205. [CrossRef]

19. Cai, R.; Wang, Q.; Xu, J.; Zhou, L. Effectiveness of Students' Self-Regulated Learning during the COVID-19 Pandemic. Sci Insigt 2020, 175-182. [CrossRef] 
20. Moore, J.L.; Dickson-Deane, C.; Galyen, K. e-Learning, online learning, and distance learning environments: Are they the same? Internet High. Educ. 2011, 14, 129-135. [CrossRef]

21. Taşçı, G.; Titrek, O. Evaluation of Lifelong Learning Centers in Higher Education: A Sustainable Leadership Perspective. Sustainability 2019, 12, 22. [CrossRef]

22. Titrek, O.; Gunes, D.Z.; Sezen, G. Higher education and lifelong learning (llp): A model proposal. In Proceedings of the International Conference on Quality in Higher Education; ICQH 2013 Proceedings Book. Sakarya University: Sakarya, Turkey, 2013; pp. 1117-1130.

23. Sanchez-Gordon, S.; Luján-Mora, S. How could MOOCs become accessible? The case of edX and the future of inclusive online learning. J. Univers. Comp. Sci. 2016. [CrossRef]

24. Bates, T. What's Right and What's Wrong about Coursera-Style MOOCs. Available online: https://www.tonybates. ca/2012/08/05/whats-right-and-whats-wrong-about-coursera-style-moocs/ (accessed on 15 October 2020).

25. Chen, K.-C.; Jang, S.-J. Motivation in online learning: Testing a model of self-determination theory. Comput. Hum. Behav. 2010, 26, 741-752. [CrossRef]

26. Barnard-Brak, L.; Paton, V.O.; Lan, W.Y. Profiles in self-regulated learning in the online learning environment. Int. Rev. Res. Open Distrib. Learn. 2010, 11, 61. [CrossRef]

27. Van Halem, N.; van Klaveren, C.; Drachsler, H.; Schmitz, M.; Cornelisz, I. Tracking Patterns in Self-Regulated Learning Using Students' Self-Reports and Online Trace Data. Front. Learn. Res. 2020, 8, 140-163. [CrossRef]

28. Boekaerts, M.; Corno, L. Self-Regulation in the Classroom: A Perspective on Assessment and Intervention. Appl. Psychol. 2005, 54, 199-231. [CrossRef]

29. Rheinberg, F.; Vollmeyer, R.; Rollett, W. Motivation and Action in Self-Regulated Learning. In Handbook of Self-Regulation; Elsevier: Amsterdam, The Netherlands, 2000; pp. 503-529.

30. Puustinen, M.; Pulkkinen, L. Models of Self-regulated Learning: A review. Scand. J. Educ. Res. 2001, 45, $269-286$. [CrossRef]

31. Corno, L.; Mandinach, E.B. The role of cognitive engagement in classroom learning and motivation. Educ. Psychol. 1983, 18, 88-108. [CrossRef]

32. Boyer, S.L.; Edmondson, D.R.; Artis, A.B.; Fleming, D. Self-Directed Learning. J. Mark. Educ. 2014, 36, $20-32$. [CrossRef]

33. Doyle, H.; Parrish, M. Investigating Students' Ways to Learn English Outside of Class: A Researchers' Narrative. Stud. Self Access Learn. J. 2012, 3, 196-203. [CrossRef]

34. Nicol, D.J.; Macfarlane-Dick, D. Formative assessment and self-regulated learning: A model and seven principles of good feedback practice. Stud. High. Educ. 2006, 31, 199-218. [CrossRef]

35. Boekaerts, M. The Interface between Intelligence and Personality as Determinants of Classroom Learning. In International Handbook of Personality and Intelligence; Springer: Boston, MA, USA, 1995; pp. 161-183.

36. Boekaerts, M. Personality and the psychology of learning. Eur. J. Pers. 1996, 10, 377-404. [CrossRef]

37. Boekaerts, M. Teaching students self-regulated learning: A major success in applied research. In Contemporary Psychology in Europe; Georgas, J., Manthouli, M., Besevegis, E., Kokkevi, A., Eds.; Hogrefe: Göttingen, Germany; Huber: Seattle, WA, USA, 1995; pp. 245-259.

38. Borkowski, J.G.; Chan, L.K.S.; Muthukrishna, N. A process-oriented model of metacognition: Links between motivation and executive functioning of metacognition. In Issues in the Measurement of Metacognition; University of Nebraska-Lincoln: Lincoln, NE, USA, 2000; pp. 1-41.

39. Zimmerman, B.J. Self-regulating academic learning and achievement: The emergence of a social cognitive perspective. Educ. Psychol. Rev. 1990, 2, 173-201. [CrossRef]

40. Zimmerman, B.J. Self-Regulated Learning and Academic Achievement: An Overview. Educ. Psychol. 1990, 25, 3-17. [CrossRef]

41. Zimmerman, B.J. Academic studing and the development of personal skill: A self-regulatory perspective. Educ. Psychol. 1998, 33, 73-86. [CrossRef]

42. Zimmerman, B.J. Attaining Self-Regulation. In Handbook of Self-Regulation; Elsevier: Amsterdam, The Netherlands, 2000; pp. 13-39.

43. Zimmerman, B.J. A social cognitive view of self-regulated academic learning. J. Educ. Psychol. 1989, 81, 329-339. [CrossRef]

44. Williams, P.E.; Hellman, C.M. Differences in Self-Regulation for Online Learning between First- and Second-Generation College Students. Res. High. Educ. 2004, 45, 71-82. [CrossRef] 
45. Crosnoe, R.; Johnson, M.K.; Elder, G.H. Intergenerational Bonding in School: The Behavioral and Contextual Correlates of Student-Teacher Relationships. Sociol. Educ. 2004, 77, 60-81. [CrossRef]

46. Daniels, D.H.; Meece, J.L. Child \& Adolescent Development for Educators; McGraw Hill: New York, NY, USA, 2008.

47. Cain, K.; Oakhill, J.V.; Barnes, M.A.; Bryant, P.E. Comprehension skill, inference-making ability, and their relation to knowledge. Mem. Cogn. 2001, 29, 850-859. [CrossRef] [PubMed]

48. Van den Broek, P.; Kendeou, P.; Lousberg, S.; Visser, G. Preparing for reading comprehension: Fostering text comprehension skills in preschool and early elementary school children. Int. Electron. J. Elem. Educ. 2011, 4, 259-268.

49. Coffey, A.; Berlach, R.G.; O'Neill, M. Transitioning Year 7 Primary Students to Secondary Settings in Western Australian Catholic Schools: How Successful Was the Move? RMLE Online 2013, 36, 1-15. [CrossRef]

50. Kift, S.; Nelson, K.; Clarke, J. Transition pedagogy: A third generation approach to FYE-A case study of policy and practice for the higher education sector. Int. J. First Year High. Educ. 2010, 1. [CrossRef]

51. Paechter, M.; Maier, B. Online or face-to-face? Students' experiences and preferences in e-learning. Internet High. Educ. 2010, 13, 292-297. [CrossRef]

52. Anderman, L.H. Academic and social perceptions as predictors of change in middle school students' sense of school belonging. J. Exp. Educ. 2003, 72, 5-22. [CrossRef]

53. Goldstein, S.E.; Boxer, P.; Rudolph, E. Middle School Transition Stress: Links with Academic Performance, Motivation, and School Experiences. Contemp. Sch. Psychol. 2015, 19, 21-29. [CrossRef]

54. Eccles, J.S.; Roeser, R.W. Schools as Developmental Contexts during Adolescence. In Handbook of Psychology, 2nd ed.; John Wiley \& Sons, Inc.: Hoboken, NJ, USA, 2012.

55. Eccles, J.S.; Midgley, C.; Wigfield, A.; Buchanan, C.M.; Reuman, D.; Flanagan, C.; Mac Iver, D. Development during adolescence: The impact of stage-environment fit on young adolescents' experiences in schools and in families. In The Evolution of Psychology: Fifty Years of the American Psychologist; American Psychological Association: Washington, DC, USA, 1993; pp. 475-501.

56. Deci, E.L.; Ryan, R.M. A motivational approach to self: Integration in personality. In Current Theory and Research in Motivation; Dienstbier, R.A., Ed.; University of Nebraska Press: Lincoln, NE, USA, 1991; Volume 38, pp. 237-288.

57. Deci, E.L.; Ryan, R.M. Human Autonomy. In Efficacy, Agency, and Self-Esteem; Springer: Boston, MA, USA, 1995; pp. 31-49.

58. Ntoumanis, N.; Edmunds, J.; Duda, J.L. Understanding the coping process from a self-determination theory perspective. Br. J. Health Psychol. 2009, 14, 249-260. [CrossRef] [PubMed]

59. Pintrich, P.R.; de Groot, E.V. Motivational and self-regulated learning components of classroom academic performance. J. Educ. Psychol. 1990, 82, 33-40. [CrossRef]

60. Ennis, C.D. Educating Students for a Lifetime of Physical Activity: Enhancing Mindfulness, Motivation, and Meaning. Res. Q. Exerc. Sport 2017, 88, 241-250. [CrossRef]

61. Elliot, A.J.; Harackiewicz, J.M. Approach and avoidance achievement goals and intrinsic motivation: A mediational analysis. J. Pers. Soc. Psychol. 1996, 70, 461-475. [CrossRef]

62. Stoeber, J.; Stoll, O.; Pescheck, E.; Otto, K. Perfectionism and achievement goals in athletes: Relations with approach and avoidance orientations in mastery and performance goals. Psychol. Sport Exerc. 2008, 9, 102-121. [CrossRef]

63. Ames, C.; Archer, J. Achievement Goals in the Classroom: Students' Learning Strategies and Motivation Processes. J. Educ. Psychol. 1988, 80, 260-267. [CrossRef]

64. Dweck, C.S. Motivational processes affecting learning. Am. Psychol. 1986, 41, 1040-1048. [CrossRef]

65. Dweck, C.S.; Leggett, E.L. A social-cognitive approach to motivation and personality. Psychol. Rev. 1988, 95, 256-273. [CrossRef]

66. Meece, J.L.; Blumenfeld, P.C.; Hoyle, R.H. Students' goal orientations and cognitive engagement in classroom activities. J. Educ. Psychol. 1988, 80, 514-523. [CrossRef]

67. Barber, B.K.; Olsen, J.A. Assessing the Transitions to Middle and High School. J. Adolesc. Res. 2004, 19, 3-30. [CrossRef]

68. Rudolph, K.D.; Lambert, S.F.; Clark, A.G.; Kurlakowsky, K.D. Negotiating the Transition to Middle School: The Role of Self-Regulatory Processes. Child. Dev. 2001, 72, 929-946. [CrossRef] [PubMed] 
69. Hines, M.T. Adolescent Adjustment to the Middle School Transition: The Intersection of Divorce and Gender in Review. RMLE Online 2007, 31, 1-15. [CrossRef]

70. Toytok, E.; Gürel, S. Does Project Children's University Increase Academic Self-Efficacy in 6th Graders? A Weak Experimental Design. Sustainability 2019, 11, 778. [CrossRef]

71. Titrek, O.; Çetin, C.; Kaymak, E.; Kaşikçi, M.M. Academic Motivation and Academic Self-Efficacy of Prospective Teachers. J. Educ. Train. Stud. 2018, 6, 77. [CrossRef]

72. Cavas, P. Factors Affecting the Motivation of Turkish Primary Students for Science Learning. Sci. Educ. Int. 2011, 22, 31-42.

73. Lee, J.C.K.; Yin, H.; Zhang, Z. Exploring the influence of the classroom environment on students' motivation and self-regulated learning in Hong Kong. Asia Pacific Educ. Res. 2009, 18, 219-232. [CrossRef]

74. Hanrahan, M. The effect of learning environment factors on students' motivation and learning. Int. J. Sci. Educ. 1998, 20, 737-753. [CrossRef]

75. Hassandra, M.; Goudas, M.; Chroni, S. Examining factors associated with intrinsic motivation in physical education: A qualitative approach. Psychol. Sport Exerc. 2003, 4, 211-223. [CrossRef]

76. Sichivitsa, V.O. The influences of parents, teachers, peers and other factors on students' motivation in music. Res. Stud. Music Educ. 2007, 29, 55-68. [CrossRef]

77. Graham, S.; Courtney, L.; Tonkyn, A.; Marinis, T. Motivational trajectories for early language learning across the primary-secondary school transition. Br. Educ. Res. J. 2016, 42, 682-702. [CrossRef]

78. Spinath, B.; Steinmayr, R. Longitudinal Analysis of Intrinsic Motivation and Competence Beliefs: Is There a Relation Over Time? Child. Dev. 2008, 79, 1555-1569. [CrossRef] [PubMed]

79. Harter, S.; Whitesell, N.R.; Kowalski, P. Individual Differences in the Effects of Educational Transitions on Young Adolescent's Perceptions of Competence and Motivational Orientation. Am. Educ. Res. J. 1992, 29, 777-807. [CrossRef]

80. Bru, E.; Stornes, T.; Munthe, E.; Thuen, E. Students' Perceptions of Teacher Support Across the Transition from Primary to Secondary School. Scand. J. Educ. Res. 2010, 54, 519-533. [CrossRef]

81. Hughes, J.N.; Cao, Q. Trajectories of teacher-student warmth and conflict at the transition to middle school: Effects on academic engagement and achievement. J. Sch. Psychol. 2018, 67, 148-162. [CrossRef]

82. Thévenon, O. Family policies in Europe: Available databases and initial comparisons. Vienna Yearb. Popul. Res. 2008, 6, 165-177. [CrossRef]

83. Norris, P. Women's legislative participation in Western Europe. West. Eur. Polit. 1985, 8, 90-101. [CrossRef]

84. Vinnicombe, S. The position of women in management in Europe. Women Manag. Curr. Res. Issues 2000, 2, 9-25.

85. Trauth, E.M.; Quesenberry, J.L.; Huang, H. Retaining women in the U.S. IT workforce: Theorizing the influence of organizational factors. Eur. J. Inf. Syst. 2009, 18, 476-497. [CrossRef]

86. Srivastava, S. Women in Workforce: Work and Family Conflict. Manag. Labour Stud. 2007, 32, 411-421. [CrossRef]

87. Örs, M. The Self-Directed Learning Readiness Level of the Undergraduate Students of Midwife and Nurse in Terms of Sustainability in Nursing and Midwifery Education. Sustainability 2018, 10, 3574. [CrossRef]

88. Smedley, A. The self-directed learning readiness of first year bachelor of nursing students. J. Res. Nurs. 2007, 12, 373-385. [CrossRef]

89. Hyde, J.S.; Linn, M.C. Gender differences in verbal ability: A meta-analysis. Psychol. Bull. 1988, 104, 53. [CrossRef]

90. Pintrich, P.R.; Zusho, A. Student Motivation and Self-Regulated Learning in the College Classroom. In Higher Education: Handbook of Theory and Research; Springer: Dordrecht, The Netherlands, 2002; pp. 55-128.

91. Voyer, D.; Voyer, S.D. Gender differences in scholastic achievement: A meta-analysis. Psychol. Bull. 2014, 140, 1174. [CrossRef]

92. Lietz, P. A meta-analysis of gender differences in reading achievement at the secondary school level. Stud. Educ. Eval. 2006, 32, 317-344. [CrossRef]

93. Pintrich, P.R.; Garcia, T. Self-regulated learning in college students: Knowledge, strategies, and motivation. In Student Motivation, Cognition, and Learning: Essays in Honor of Wilbert J. Mckeachie; Taylor \& Francis Group: London, UK, 1994; pp. 113-133. 
94. West, P.; Sweeting, H.; Young, R. Transition matters: Pupils' experiences of the primary-secondary school transition in the West of Scotland and consequences for well-being and attainment. Res. Pap. Educ. 2010, 25, 21-50. [CrossRef]

95. Snape, M.D.; Viner, R.M. COVID-19 in children and young people. Science 2020, 1-3. [CrossRef]

96. Eccles, J.S.; Roeser, R.W. School and community influences on human development. In Developmental Science: An Advanced Textbook; Bornstein, M.H., Lamb, M.E., Eds.; Psychology Press: Hove, East Sussex, UK, 2011; pp. 571-643.

97. Grolnick, W.S. The role of parents in facilitating autonomous self-regulation for education. Theory Res. Educ. 2009, 7, 164-173. [CrossRef]

98. Van Rens, M.; Haelermans, C.; Groot, W.; Maassen van den Brink, H. Facilitating a Successful Transition to Secondary School: (How) Does it Work? A Systematic Literature Review. Adolesc. Res. Rev. 2018, 3, 43-56. [CrossRef]

99. Wampler, R.S.; Munsch, J.; Adams, M. Ethnic Differences in Grade Trajectories during the Transition to Junior High. J. Sch. Psychol. 2002, 40, 213-237. [CrossRef]

100. Huon, G.; Spehar, B.; Adam, P.; Rifkin, W. Resource use and academic performance among first year psychology students. High. Educ. 2007, 53, 1-27. [CrossRef]

Publisher's Note: MDPI stays neutral with regard to jurisdictional claims in published maps and institutional affiliations.

(C) 2020 by the authors. Licensee MDPI, Basel, Switzerland. This article is an open access article distributed under the terms and conditions of the Creative Commons Attribution (CC BY) license (http://creativecommons.org/licenses/by/4.0/). 